\title{
Recorregut de recerca geològica i mineralògica per la Vall de Ribes (comarca del Ripollès): des de Ribes de Freser, a Pardines, Serrat, Queralbs, Batet i Ventolà
}

Josep Maria Mata-Perelló

Joaquim Sanz Balagué

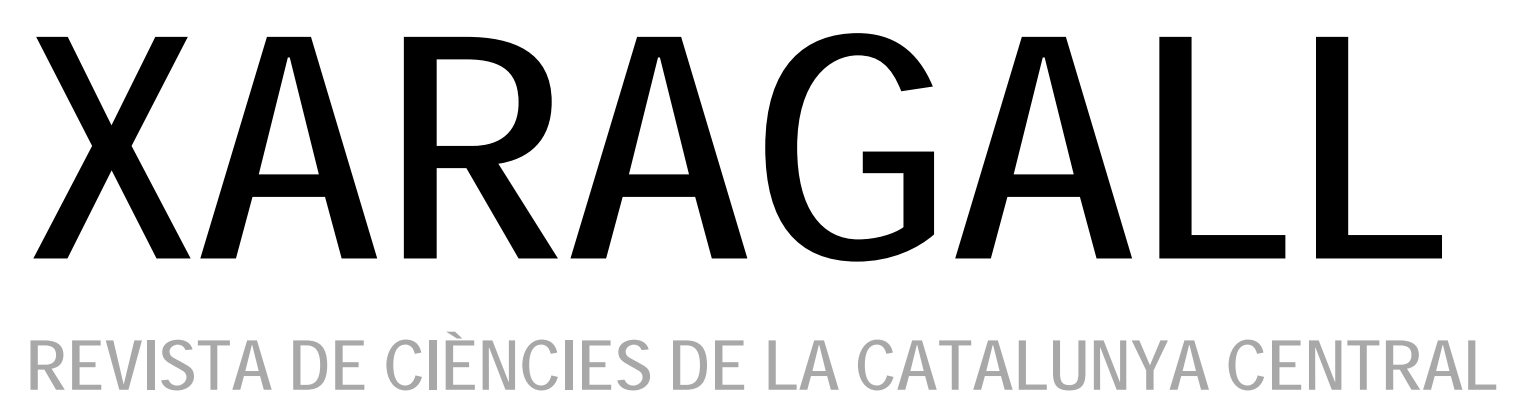

\section{n. 7}

JULIOL 2014 


\section{RECORREGUT DE RECERCA GEOLÒGICA I MINERALÒGICA PER LA VALL DE RIBES (COMARCA DEL RIPOLLĖS): DES DE RIBES DE FRESER, A PARDINES, SERRAT, QUERALBS, BATET I VENTOLÀ}

\section{Josep Maria Mata-Perelló}

Museu de geologia Valentí Masachs, Escola Politècnica Superior d'Enginyeria de Manresa (EPSEM), Universitat Politècnica de Catalunya · BarcelonaTech (UPC), 08272 Manresa, Spain

\section{Joaquim Sanz Balagué}

Departament d'Enginyeria Minera i Recursos Naturals (EMRN), Escola Politècnica Superior d'Enginyeria de Manresa (EPSEM), Universitat Politècnica de Catalunya · BarcelonaTech (UPC), 08272 Manresa, Spain

Paraules clau: Sistema Pirinenc; Pirineus Orientals; Geologia; Mineralogia

\section{Resum}

Itinerari realitzat el 23 de juny de 2013. En aquesta ocasió, el recorregut de l’itinerari discorrerà en la totalitat pel Sistema Pirinenc i més concretament pel sector dels Pirineus Orientals. Dintre d'aquests, deambularà per dos dels seus sectors més representatius: en concret per la zona dels anomenats Apilaments Antiformes del Freser, així com també per la Zona Axial, pròpiament dita. Així, el recorregut s'iniciarà dintre dels Apilaments Antiformes del Freser, pels voltants del poble de Ribes de Freser. Finalment, els darrers trams del recorregut de l'itinerari, ja s'afectaran per la Zona Axial, en la qual clourà el recorregut, en arribar a la Mina de Can Paloca, per les immediacions de Ventolà.

També cal dir, per d'altra banda, que la totalitat del recorregut, del present itinerari, es desenvoluparà per dintre de la superfície ocupada per la comarca del Ripollès, la qual pertany a la Regió de Vic. 


\section{Objectius fonamentals}

Els objectius fonamentals que es pretenen aconseguir en aquest itinerari geològic i mineralògic, són els següents:

1. Observació i estudi dels afloraments del Sistema Pirinenc, tant dels que corresponen als Apilaments Antiformes del Freser o com els de la Zona Axial, els quals anirem trobant a diferents indrets al llarg de tot el recorregut de l'itinerari.

2. Observació i estudi dels materials paleozoics (fonamentalment del Cambro-Ordovicià i de I'Ordovicià), que constitueixen tant els afloraments dels Apilaments Antiformes del Freser com els de la Zona Axial. Aquests materials els tallarem pels voltants de Ribes de Freser $\mathrm{i}$ entre aquesta població i la de Queralbs.

3. Estudi i descripció de les relacions i els contactes existents entre les tres unitats acabades d'esmentar al paràgrafs anteriors, i també entre els materials que les constitueixen. Així, ens referirem al denominat encavalcament de Ribes - Camprodon. el qual constitueix el límit meridional dels Apilaments Antiformes de Ribes.

4. Estudi i descripció de diferents mineralitzacions, que anirem veient al llarg de tot el recorregut, com les següents:

4A) de les mineralitzacions filonianes d'antimonita - arsenopirita, situades prop de Pardines (a la Collada Verda), encaixades entre els materials de I'Ordovicià.

4B) de les mineralitzacions filonianes d'arsenopirita, situades prop del Serrat (a la Creu de Fa), i també de les situades a Queralbs (a la Mina Teodora), així com a Batet (Mines Girona i Fernanda), encaixades entre els materials de l'Ordovicià

4C) de les mineralitzacions ferruginoses de rebliment de cavitats d'origen kàrstic, situades entre altres indrets prop del Ventolà (a Can Paloca), situades entre els materials carbonatats de l'Ordovicià

5. Observació de diferents explotacions mineres, relacionades amb les mineralitzacions acabades d'esmentar.

6. Observació de l'impacte produït per les mineralitzacions i explotacions anteriors, sobre el Medi Natural i sobre el Medi Ambient.

7. Observació del diferents elements, relacionats amb el patrimoni geològic i miner, que anirem trobant al llarg del recorregut. 


\section{Antecedents}

$\mathrm{Hi}$ ha alguns antecedents, relatius a itineraris geològics i mineralògics, el quals discorren per indrets propers al present. Entre aquests, farem esment de diversos treballs nostres, com els següents: Mata-Perelló (1995, 1996a, 1996b, 1997, 1998, 2007, 2011a i 2011b). També farem esment de Mata-Perelló i Sanz Balagué (1991).

Pel que fa a les mineralitzacions que veurem en aquest itinerari, cal dir que ja estat prèviament descrites per nosaltres en un altre treball (d'àmbit general referit al conjunt de Catalunya), al qual ens remetin; es tracta de Mata-Perelló (1991). Tanmateix farem referència als treballs de Ayora (1981) i de Sunyer (1992)

Per d'altra banda, en canvi, farem esment de diversos treballs, de caràcter geològic general i regional, com són els següents: Guimerà et altri (1992), i Riba et altri (1976). Tanmateix, i pel que fa a les monografies regionals, farem esment dels següents treballs: IGME (1991 i 1994).

Tots aquests treballs, figuren convenientment referenciats, per estricte ordre alfabètic, dintre de I'apartat dedicat a les REFERÈNCIES BIBLIOGRÀFIQUES, al qual ens remetin.

\section{Recorregut de l'itinerari}

El recorregut de l'itinerari, s'iniciarà a la població de Ribes de Freser, des d'on es farà un primer recorregut per tal d'anar cap a la propera població de Pardines (circulant per la carretera local GiV - 5262). Des d'aquí es farà una fillola (millor a peu), per tal d'anar cap a les Mines de la Collada Verda.

Després, caldrà retornar cap a Pardines i cap a Ribes de Freser. Ara, a partir d'aquí, ens convindrà anar cap el Nord, cap a les immediacions de Queralbs (seguint la carretera local GiV - 5217), fins a trobar el trencall que es dirigeix cap el poble del Serrat. Des d'aquí, per un camí de terra (millor a peu), ens convindrà anar cap a les Mines de la Creu de Fa, per tal de fer una nova aturada.

Després de realitzar la fillola anterior, ens caldrà retornar a la carretera que es dirigeix cap a Queralbs (la GiV - 5271). En arribar al poble, ens caldrà continuar pel camí que va cap a la Fontalba. Així, arribarem a la Mina Teodora, per on farem una nova aturada.

Tot seguit, després de retornar a les immediacions de Queralbs, ens caldrà tornar per la carretera GiV - 5271, fins a trobar el trencall de Batet, per la dreta de la ruta que seguim. A partir d'aquesta carretera, realitzarem diverses filloles, per tal d'anar cap a la Mina Girona i cap a la Mina Fernanda, després de sobrepassar Batet. Posteriorment, en baixar des del darrer poble, cap a la carretera de Ribes, ens caldrà agafar el trencall de Possons i de Segura, des d'on podem anar a peu a les Mines de Can Paloca, de Ventolà, entre altres indrets.

\section{Advertiments previs}


Com en altres recorreguts de RECERCA GEOLÒGICA I MINERALÒGICA ..., semblants al present, si es disposa del temps suficient, poden efectuar-se passant per totes les parades $\mathrm{i}$ filloles indicades al present guió. En cas contrari, recomanem prescindir de les anomenades PARADES - CONDICIONALS.

Cal dir també, que en aquest itinerari ens trobarem devent de tres trams de camins forestals en molt mal estat de conservació; per la qual cosa serà molt millor transitar a peu per ells. En aquest itinerari, hi ha alguns trams de terra, com el que es dirigeix des de Pardines a les Mines de la Collada Verda; o el del Serrat a les Mines de la Creu del Fa; o el de Batet a la Mina Fernanda i a la Mina Girona; així com el d'aproximació a les Mines de Can Paloca, de Ventolà (des d'aquest poble o des de Batet).

En qualsevol cas, cal tenir sempre una cura molt especial de respecte a la natura, al llarg de tot el recorregut; de l'itinerari.

\section{Descripció de l'itinerari}

Com de costum, estructurarem el recorregut de l'itinerari en una sèrie de PARADES (o d'ESTACIONS), que tot seguit anirem veient. En cadascuna d'aquestes aturades farem un breu comentari (geològic o mineralògic, segons s'escaigui). Per d'altra banda, en cada cas indicarem, entre parèntesi, el full topogràfic on es troba l'aturada.

Per d'altra banda, en cadascuna de les parades, indicarem entre parèntesi el número del "Mapa Topográfico", a escala 1:50.000, on es troba situada la parada considerada. Finalment, cal dir que el recorregut de l'itinerari s'inclourà dintre dels següents fulls: 217 (dit de Puigcerdà), 218 (o de Molló), 255 (dit de la Pobla de Lillet) i 256 (o de Ripoll).

Així doncs, la relació general ordenada de les parades que constitueixen aquest itinerari, és la següent:

\subsection{Parada 1 - CONDICIONAL. MINES DEL SERRAT DE LA GUILLA, (terme municipal de Pardines, comarca del Ripollès). (Full 256).}

El recorregut de l'itinerari el començarem a la població de Ribes de Freser. Des d'aquí, ens caldrà agafar la carretera local GiV-5262, la qual es dirigeix cap a Pardines (arribant-se en uns $6 \mathrm{Km}$ ). Tot seguit cal seguir la pista que es dirigeix cap a la Collada Verda, tot i que es millor seguir-la a peu. En arribar al Torrent de la Pietat, ens caldrà agafar el camí que puja al Serrat de la Guilla, on hi ha unes mines. Aquí farem la primera aturada, a poc més de $1 \mathrm{Km}$ del poble $\mathrm{i}$ a uns $7 \mathrm{Km}$ de l'inici del recorregut.

En un principi, aquest recorregut, s' haurà efectuat entre afloraments dels nivells esquistosos de I'Ordovicià, entre els quals es troben freqüents intercalacions de calcàries i de dolomies. Aquests materials s'inclouen en la zona dels Apilaments Antiformes del Freser, per on ha deambulat el recorregut de l'itinerari des de la parada anterior, fins poc després de sobrepassar Ribes de Freser. Poc després de trobar el camí de Tragurà, hem sobrepassat l'encavalcament de Ribes - Camprodon, que aquí posa en contacte els materials abans esmentats dels Apilaments Antiformes de Ribes, amb el també paleozoics de I'Ordovicià de la Zona Axial, on ara ens trobem situats.

En aquest indret hi ha unes mineralitzacions filonianes, les quals es troben situades entre els afloraments esquistosos de la Formació Canavelles de I'Ordovicià. Entre els minerals presents, 
cal fer esment dels següents: ARSENOPIRITA, CALCOPIRITA, GALENA, PIRITA, així com diversos minerals d'alteració.

\subsection{Parada 2 - CONDICIONAL. MINES DE LA COLLADA VERDA, (terme municipal de Pardines, comarca del Ripollès). (Full 256).}

Després de realitzar la parada anterior, cal continuar el camí que va ascendint cap a la Collada Verda. Tot i que el camí es transitable en tot terrenys, es millor fer el recorregut a peu, passant per diversos indrets com el Torrent de Vallinfern i les immediacions de Boixatera. En arribar a I'esmentada Collada Verda, ja veurem les escombreres de les mines. Aquí, farem una nova aturada, després d'un recorregut d'uns $4-5 \mathrm{Km}$, ascendents.

Aquest recorregut, l'haurem fet entre els afloraments dels materials esquistosos de l'Ordovicià, que en bona part pertanyen a la Formació Canavelles. Aquests són els materials que es troben a l'indret de la present aturada, dintre de la Zona Axial Pirinenca.

Les mineralitzacions es relacionen amb filons de direcció WNW - ESE, encaixades entre els esquistos de I'Ordovicià. Es tracta de mineralitzacions fonamentalment de caràcter As - Sb, amb presencia dels següents minerals: ARSENOPIRITA, CALCOPIRITA, ESTIBINA, MARCASSITA, PIRITA; així com diversos minerals d'oxidació d'aquests sulfurs.

$\mathrm{Hi}$ ha diverses explotacions (que segueixen pel terme d'Abella). Així, es fan paleses nombroses escombreres, sense cap mena de vegetació (per la presencia dels minerals d'arsènic $i$ d'antimoni). (fotografía 1).

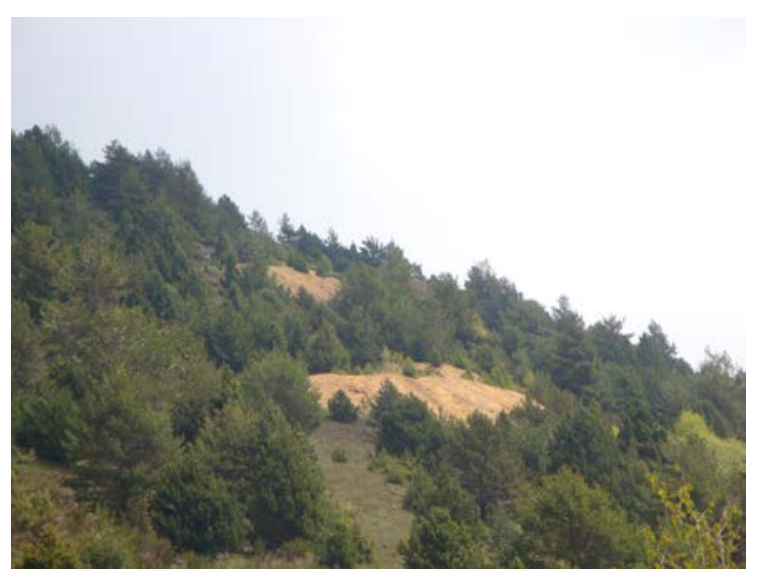

Fotografia 1. Escombreres de les Mines de la Collada Verda, Pardines

\subsection{Parada 3 - CONDICIONAL. MINES DE RIALB, (Rialb, terme municipal de Queralbs, comarca del Ripollès). (Full 218).}

Després de realitzar el recorregut anterior, ens caldrà retornar cap a Pardines i posteriorment cap a la població de Ribes de Freser. Ara, des d'aquí, ens caldrà agafar la carretera local GiV- 
5217, la qual es dirigeix cap a Rialb. En arribar-hi, haurem de continuar a peu, per tal d'arribar al paratge on hi ha les Coves de Can Damià. En aquest indret farem una nova aturada, a uns 3 $\mathrm{Km}$ de Ribes de Freser i a uns $14 \mathrm{Km}$ de la parada anteriorment realitzada, aproximadament.

En retornar cap a Ribes de Freser, haurem trobat els materials dels que ja hem parlat en els recorreguts cap a les dues primeres aturades. Després, des de Ribes, aquest recorregut cap el Nord, s' haurà efectuat entre afloraments dels nivells esquistosos de l'Ordovicià, entre els quals es troben freqüents intercalacions de calcàries i de dolomies. Aquests materials s'inclouen en la zona dels Apilaments Antiformes del Freser, per on ha deambulat el recorregut de I'itinerari des de la parada anterior, fins poc després de sobrepassar Ribes de Freser; doncs en trobar el camí-carretera de Batet, hem sobrepassat l'encavalcament de Ribes - Camprodon, que aquí posa en contacte els materials abans esmentats dels Apilaments Antiformes de Ribes, amb el també paleozoics de I'Ordovicià de la Zona Axial, on ara ens trobem situats. En aquest indret apareixen uns trams carbonatats del Devonià.

Precisament sobre aquests trams s' han originat les formacions kàrstiques que han donat lloc a les coves de Can Damià, les quals es troben prop d'on ara estem situats. Per d'altra banda, en aquest indret hi ha una mineralització filoniana que encaixa entre les esmentades calcaries. Entre els minerals presents, cal fer esment dels següents: ARSENOPIRITA, CALCOPIRITA, GALENA, PIRITA, així com diversos minerals d'alteració.

Finalment, cal dir que aquesta mineralització ha estat explotada en una antiga mineta, situada molt prop de la via del Cremallera.

\subsection{Parada 4. MINES DE LA CREU DE FA. MINA MARIA, (EI Serrat, terme municipal de Queralbs, comarca del Ripollès). (Full 218).}

Després de realitzar la parada anterior, cal retornar a la carretera local GiV-5217, la qual es dirigeix ara cap a Rialb, tot remuntant el riu Freser. Poc després de deixar el trencall de Vilamalla (per l'esquerra), quasi en començar la pujada cap a Queralbs, trobarem per la dreta el trencall del Serrat, cap on ens caldrà anar. Després de sobrepassar el poblet, haurem de continuar ascendint, per tal d'arribar a la Creu de Fa. En aquest indret, a uns $2 \mathrm{Km}$ del Serrat i a uns 11 de la parada anterior, n' efectuarem una altra.

En aquest recorregut, hem continuat trobant els materials paleozoics de l'Ordovicià, els quals formen part de la Zona Axial Pirenaica, on ara ens trobem situats a l'indret de la present aturada. Aquests materials es troben representats per nivells d'esquistos de la Formació Canavelles.

En aquest indret es fan clarament paleses unes escombreres, que corresponen a unes antigues explotacions mineres. En aquestes es van intentar beneficiar els minerals d'uns filonets encaixats entre els materials de l'Ordovicià. Els minerals primaris presents son els següents: ARSENOPIRITA, CALCOPIRITA, ESTIBINA, GALENA, PIRITA; així com diversos minerals d'alteració formats a partir dels anteriors. (fotografía 2). 


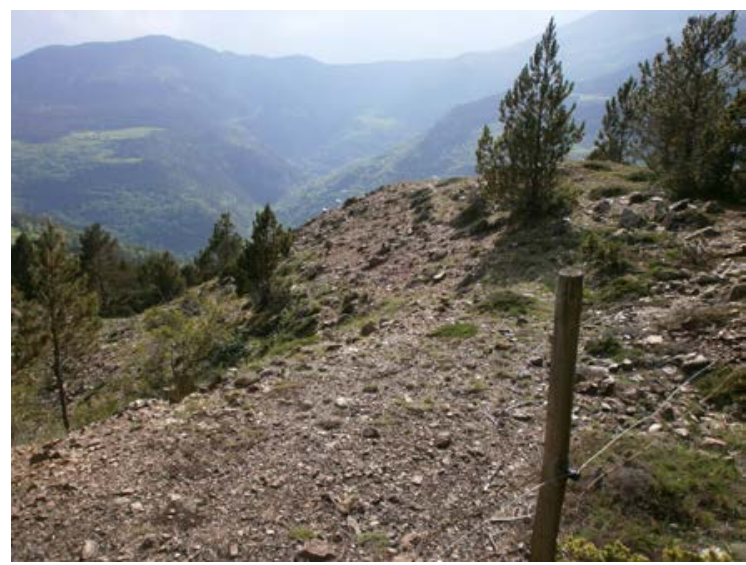

Fotografia 2.Escombreres de la Mina de la Creu de Fa, El Serrat

\subsection{Parada 5. PONT DE DAIÓ, (la Farga, terme municipal de Queralbs, comarca del Ripollès). (Full 218).}

Després de realitzar la parada anterior, cal retornar quasi fins a la carretera GiV-5217. Tot i així, en arribar al riu, trobarem la carretereta que el remunta fins a la Central Hidroelèctrica de Daió, situada prop del Pont de Daió. En aquest indret farem una nova aturada, després de remuntar poc més de $1^{\prime} 5 \mathrm{Km}$ i a uns $7-8 \mathrm{Km}$ de la parada anterior.

En aquest recorregut, hem trobat els materials ja esmentats a l'aturada anterior. Així, com als recorreguts anteriors, ens trobem dintre de la Zona Axial Pirinenca. Tot i així, es fan força palesos els afloraments dels materials granítics.

En aquest indret, on hi ha una Central Hidroelèctrica, es produeix l'aiguabarreig del Riu Nuria (que baixa del Nord) i del Riu Fresser (procedent del NE). (fotografia 3).

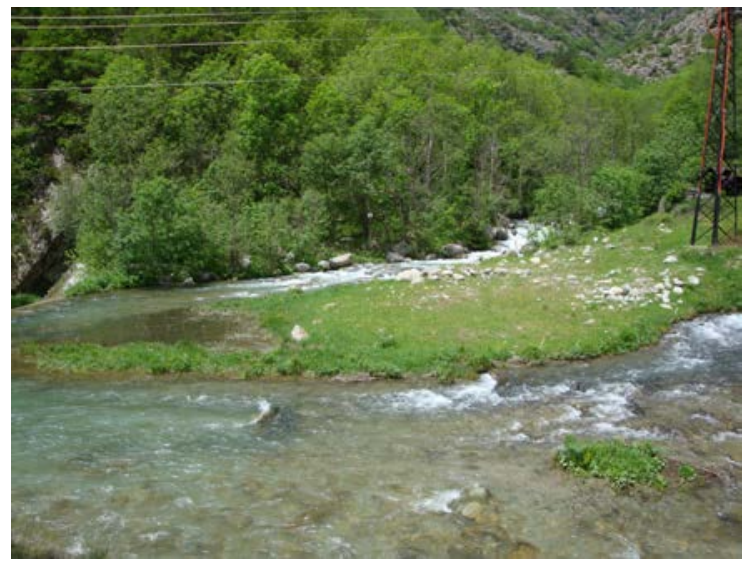

Fotografia 3. En primer terme el Riu Freser (procedent de Coma de Vaca) i en segon terme el Riu Nuria (procedent de la vall del mateix nom). La Farga 
Per d'altra banda, en aquest recorregut entre la carretera de Queralbs i el Pont de Daió, hem passat prop de la Mina de lelles, la qual es troba situada per sobre la carretera que hem seguit. Es tracta d'una mina molt semblant a les que hem trobat a Pardines, amb presencia d'ARSENOPIRITA i d'abundants òxids de ferro (GOETHITA i HEMATITES).

\subsection{Parada 6. MINA TEODORA. CAMÍ DE FONTALBA, (terme municipal de Queralbs, comarca del Ripollès). (Full 217).}

Després d'efectuar la parada anterior, cal retornar a la carretera GiV-5217. En trobar-la, ens haurem de dirigir cap el proper poble de Queralbs. Quasi a l'entrada, trobarem el camí asfaltat que es dirigeix cap a Fontalba. Ens convindrà agafar-lo. Aquest camí es va enlairant poc a poc. Més endavant, després de trobar per l'esquerra el camí de Can Puig, arribarem a l'antiga Mina Teodora. Aquí farem una nova aturada, després de recórrer uns $4 \mathrm{Km}$ des de la parada anterior.

En aquest recorregut, haurem trobat afloraments dels materials esmentats a les aturades anteriors. Així, sovint haurem vist els esquistos de I'Ordovicià, que aquí es troben força plegats i replegats. (fotografia 4), just on hi ha un cartell explicatiu de la mina i la bocamina inferior. (fotografia 5)..

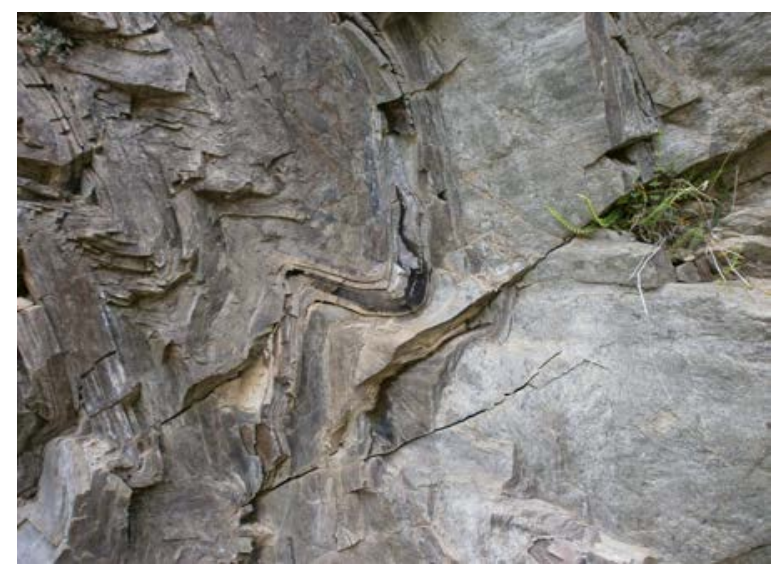

Fotografia 4. Plecs entre els esquistos de l'Ordovicià. Boca inferior de la Mina Teodora. Queralbs

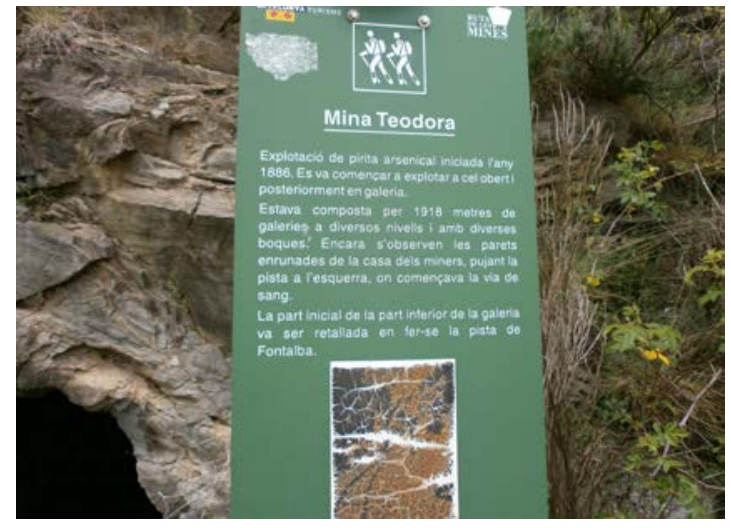

Fotografia 5. Cartell explicatiu de la Mina Teodora. Boca inferior de la Mina Teodora. Queralbs

Aquesta mineralització es de caràcter filonià, similar al de les mineralitzacions anteriors, que hem anat veient a Pardines i al Serrat. Així, es tracta de mineralitzacions d'As i Sb, amb 
presencia majoritària dels minerals d'arsènic. Així, entre altres minerals es troben: ARSENOPIRITA, CALCOPIRITA (minoritària), ESTIBINA, MARCASSITA i PIRITA. També es troben diversos minerals d'alteració, firmats a partir de I'oxidació dels sulfurs acabats d'esmentar. Molts d'aquests es troben a l'escombrera de les bocamines superiors. FOTOGRAFIA 6. Cal dir que per arribar fins a l'escombrera, cal fer-ho des del camí que condueix al Puig.

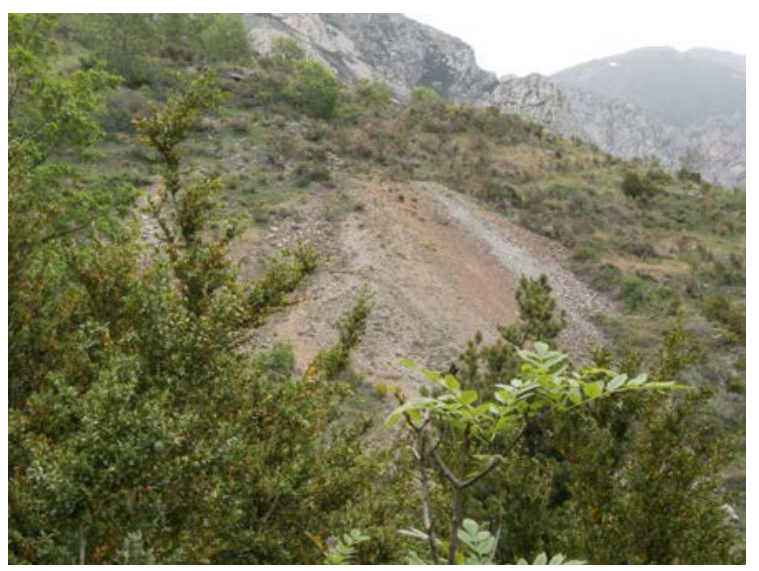

Fotografia 6. Escombrera de les boques superiors de la Mina Teodora. Queralbs

\subsection{Parada 7 - CONDICIONAL. MINA CENTELLA, (terme municipal de Queralbs, comarca del Ripollès). (Full 217).}

Després de realitzar la parada anterior, cal fer un recorregut a peu pel camí que condueix cap a Can Puig. Es tracta d'un camí prohibit, per la qual cosa cal demanar autorització per passar-hi. En arribar a la casa, cal agafar un corriol que va ascendint fins al peu d'un cingle. En aquest indret hi ha unes antigues explotacions mineres. En aquest indret farem una nova aturada, a poc més de $1 \mathrm{Km}$ des de l'anterior.

En aquest breu recorregut, hem trobat els materials esmentats a l'aturada anterior. Tot i això, ara s'han fet palesos uns nivells carbonatats. Entre aquests materials es fa palesa la mineralització. Es tracta d'unes concentracions d'òxids de ferro, amb presencia de GOETHITA (molt limonítica i terrosa) i d'HEMATITES.

Cal dir que aquí han estat explotats els minerals de ferro, en diferents èpoques. Tot i així, fonamentalment van ésser utilitzats com a matèria prima per a les fargues catalanes que hi havia vels voltants de Queralbs.

\subsection{Parada 8. MINA GERONA, (Batet, terme municipal de Ribes de Freser, comarca del Ripollès). (Full 256).}

Després de realitzar la parada anterior, cal retornar cap el poble de Queralbs. Tot seguit, cal retornar cap a les immediacions de Ribes de Freser, seguint la carretera local GiV - 5217, per 
la qual hem pujat cap a Queralbs. En aquest recorregut invers, tornarem a passar per les immediacions de Rialb. Poc després, per la dreta de la carretera (en sentit descendent), trobarem el trencall de Batet, per on anirem cap aquest poblet. Abans d'arribar, trobarem (per I'esquerra, els trencalls de Can Possons i de Segura. En arribar a Batet, ens caldrà seguir cap amunt, per un camí de terra (que serà millor seguir-ho a peu). A uns $2 \mathrm{Km}$ de Batet, després d'un giravolt, trobarem un corriol que es dirigeix cap a la Mina Gerona. Aquí farem una nova aturada, a uns $12 \mathrm{Km}$ de la parada anterior.

En aquest recorregut, haurem trobat fonamentalment els nivells d'esquistos i calcàries, que pertanyen a l'Ordovicià. Així, com als anteriors recorreguts, estem situats a la Zona Axial Pirinenca, tot i que molt a prop de l'encavalcament Ribes - Camprodon.

En aquest indret hi ha una boca de l'antiga Mina Gerona, situada al costat del Barranc de la Fernanda. La explotació es trobava situada sobre una mineralització filoniana, encaixada entre els esquistos de l'Ordovicià. La mineralització és fonamentalment d'arsènic, amb presencia majoritària d'ARSENOPIRITA. Per d'altra banda, es troben abundants minerals d'alteració.

Per d'altra banda, des d'aquest indret, es pot fer una bona observació del Taga, situat al SE d'on ara ens trobem. (fotografia 7).

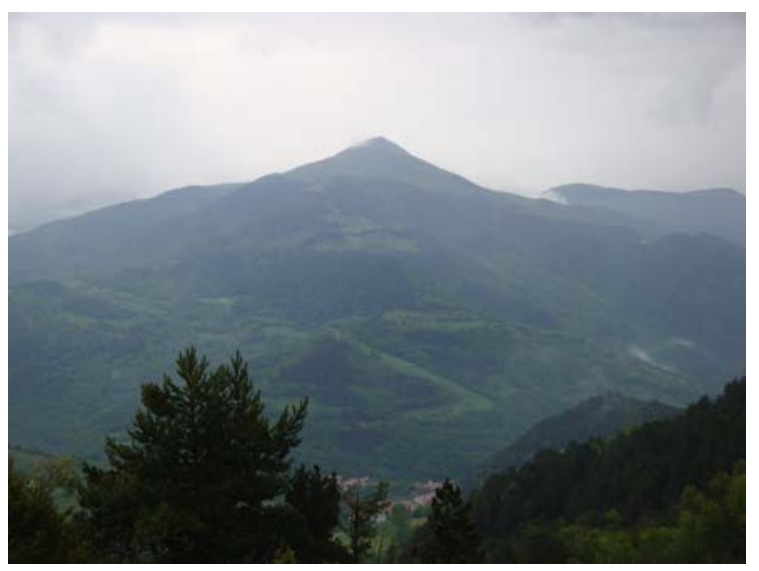

Fotografia 7. El Taga, des de la boca de la Mina Gerona. Batet
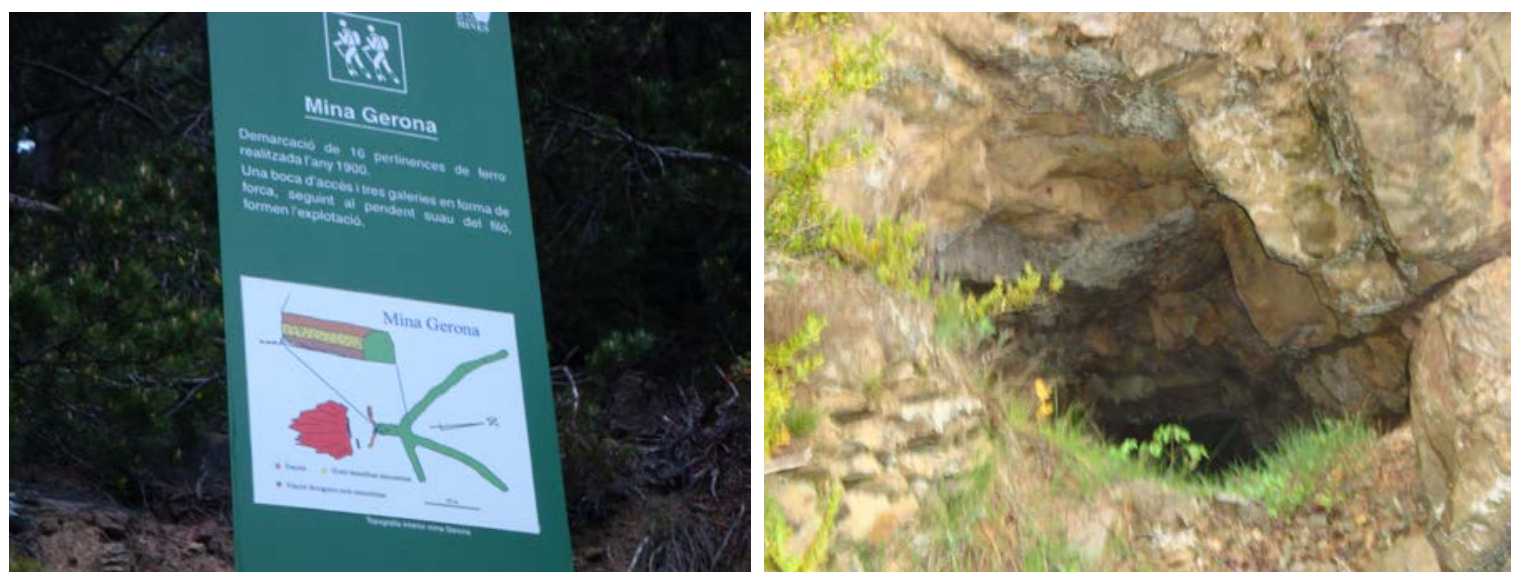

Xaragall.2014 n.7 Recorregut de recerca geològica i mineralògica per la Vall de Ribes (comarca del Ripollès): des de Ribes de Freser, a Pardines, Serrat, Queralbs, Batet i Ventolà 


\subsection{Parada 9. MINA FERNANDA, (Batet, terme municipal de Ribes de Freser, comarca del Ripollès). (Full 256).}

Des de la parada anterior, cal retornar al camí pel que hem sortit de Batet. Ens caldrà seguir-lo fins arribar a un pla, per on s'acaba el camí. Des de la part superior del pla, trobarem un corriol que condueix cap el Barranc de la Fernanda. En arribar al mateix, trobarem la Mina Fernanda, per on farem la present aturada, a poc més de 0’5 Km de la parada anterior.

Tot aquest recorregut, s'haurà efectuat entre afloraments dels nivells esquistosos de l'Ordovicià, entre els quals es troben freqüents intercalacions de calcàries i de dolomies. Aquests materials s'inclouen dintre de la denominada Zona Axial, en la qual hem estat efectuant la major part del recorregut.

En aquest indret, on efectuarem la present aturada, hi ha una interessant mineralització filoniana, la qual es troba encaixada entre els materials esquistosos de la Formació de Canavelles, la qual pertany a l'Ordovicià.

Entre els minerals primaris presents, cal fer esment dels següents: ARSENOPOIRITA (molt abundant), CALCOPIRITA, GALENA (indicis), PIRITA, CALCITA i QUARS (molt abundant). Entre els minerals d'alteració, cal fer esment dels següents: GOETHITA (terrosa i limonítica), HEMATITES (també terròs), ATZURITA. MALAQUITA, ESCORODITA i MELANTERITA. Tanmateix, hi ha presència d'indicis de CERUSSITA i d'ANGLESITA. Finalment, cal parlar de la presència d'ARAGONITA, i de dendrites de PIROLUSITA.

En aquest indret, va haver-hi unes interessants explotacions dels minerals d'arsènic; però amb la idea d'extreure l'OR NADIU, el qual es trobava disseminat entre l'arsenopirita.

\subsection{Parada 10 - CONDICIONAL. MINA DE CAN POSSONS, (Batet, terme municipal de Ribes de Freser, comarca del Ripollès). (Full 256).}

Després de fer la parada anterior, cal retornar cap el poble de Batet. Tot seguit, caldrà sortir del poble per la carretera que condueix cap a la ruta GiV - 5217 (Ribes de Freser - Queralbs), però en trobar el trencall de Can Possons i de Segura, ens caldrà agafar-lo. En arribar a les immediacions dels dos indrets, trobarem una antiga explotació minera, on farem una nova aturada, a uns $5 \mathrm{Km}$ de la parada anterior i a uns 2 de Batet.

Com als altres recorreguts, haurem circulat sempre entre els afloraments dels materials esquistosos de l'Ordovicià, trobant-nos molt a prop de l'encavalcament de Ribes - Camprodon. Així, a l'igual que les aturades anteriors, estem dintre de la Zona Axial Pirinenca.

En aquest indret, hi havia unes antigues explotacions de ferro, semblants a les que veurem a la propera aturada. Es tracta de mineralitzacions de rebliment de cavitats d'origen kàrstic, situades entre nivells de calcaries de l'Ordovicià. Els minerals de ferro més abundants són la GOETHITA (terrosa i limonítica) i I'HEMATITES (terrós). 


\subsection{Parada 11. MINES DE FERRO DE CAN PALOCA, (Ventolà, terme de Ribes de Freser, comarca del Ripollès). (Full 255).}

Després de realitzar l'aturada anterior, cal seguir cap a Can Segur i cap el Coll de Segura, per tal de seguir a peu cap al poble de Ventolà. Seguint a peu per aquest camí, arribarem a les Mines de Ferro de Can Paloca, per on farem la darrera aturada d'aquest itinerari, efectuant un recorregut d'uns 2'5 Km, des de la parada anterior.

Tot $i$ així, hi ha la possibilitat d'arribar-hi des del poble de Ventolà. En aquest cas, des de la parada anterior, cal baixar fins a la carretera local GiV - 5217, per tal d'arribar a Ribes de Freser. Tot seguit, caldrà agafar la carretera $N$ - 260 (antiga $N$ - 152), en el seu sentit septentrional, cap a la Collada de Toses, fins trobar el trencall de Ventolà, per la dreta de la carretera, des d'on surt la carretera local GiV-5218, la qual es dirigeix cap a l'esmentat poble. Poc abans d'arribar-hi, ens caldrà seguir a peu, per un camí que surt per la dreta, amb la intenció de fer una fillola que ens haurà de conduir cap a les Mines de Ferro de Can Paloca. Aquí, en arribar-hi, farem la present aturada, després de fer un recorregut proper als $174 \mathrm{Km}$, des de la parada anterior, dels quals 1'5 Km, els haurem fet a peu.

Tot aquest recorregut, s'ha efectuat íntegrament entre els nivells de lutites i ritmites de I'Ordovicià, les quals alternen amb nivells de calcàries i de dolomies. Precisament, en aquest indret, hi ha una mineralització desenvolupada sobre aquests darrers materials. És tracta d'una mineralització de rebliment de cavitats d'origen kàrstic, localitzada entre els nivells carbonatats de les calcàries.

La mineralització, consisteix en la concentració d'abundants òxids de ferro, amb presència de: GOETHITA (limonítica i terrosa), HEMATITES (terrosa) i LEPIDOCROCITA (d'un aspecte similar al de la goethita). Al mateix temps, part d'aquests quests minerals, s'han format a partir de l'oxidació de sulfurs primaris, com ARSENOPIRITA i PIRITA, fonamentalment, les quals també es troben presents a l'indici.

Per d'altra banda, també es troben presents altres minerals, com els següents: PIROLUSITA (la qual es presenta sempre terrosa i també dendrítica), CALCITA, SIDERITA i QUARS.

Aquesta mineralització va ésser explotada, per a l'obtenció dels minerals de ferro; tot i així, darrerament ha estat investigada, de cara a la prospecció dels indicis d'OR NADIU que es troben al lloc de l'indici, entre els esmentats oxids de ferro, tot formant part de la zona d'oxidació, formada a partir de l'alteració dels sulfurs primaris, entre els quals es trobava l'esmentat or nadiu.

A l'indret de l'aturada, existeixen diverses explotacions de ferro (FOTOGRAFIA 10). En conjunt, formen part del nostre Patrimoni Miner. 


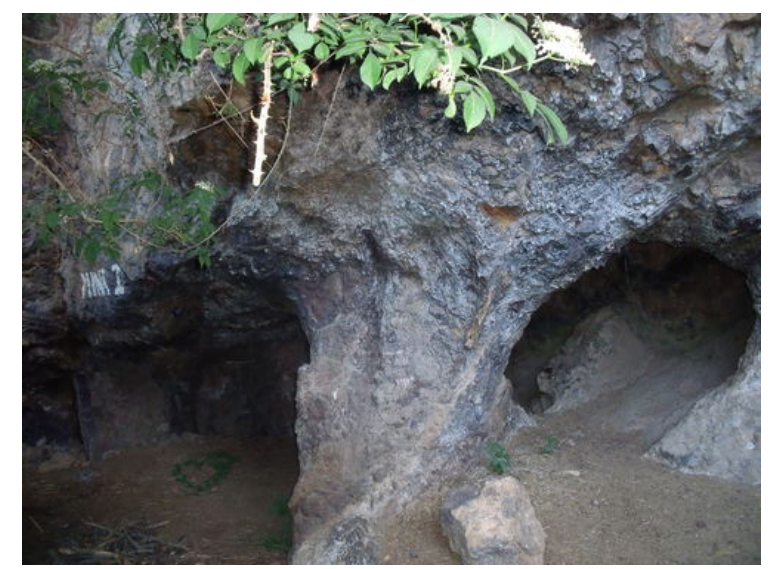

Fotografia 10. Un aspecte de les Mines de Ferro de Can Paloca. Ventolà Extreta de INTERNET: WIKILOC http://es.wikiloc.com/wikiloc/imgServer.do?id=1238581

En aquest indret finalitza el recorregut de l'itinerari.

\section{Bibliografia}

AYORA, C. (1981).- Les concentracions metàl-liques de la Val1 de Ribes. Tesi. Doctoral Universitat de Barcelona.

GUIMERÀ, J. et altri (1992).- Geologia (II), Història Natural dels Països Catalans. Vol. 2, 547 pag. Enciclopèdia Catalana, S.A., Barcelona.

IGME (1991).- Mapa Geológico de España a escala 1:50.000 (síntesis de la cartografia existente). Full i memòria número 256 (Ripoll). Inst. Tecnol. y GeoMinero de España, Minist Indústria. Madrid. 
IGME (1994).- Explicació del Mapa Geológico de España, a escala 1:50.000. Full i memòria número 255 (la Pobla de Lillet). Inst. Tecnol. y GeoMinero de España. Minist. Indústria. Madrid.

MATA-PERELLÓ, J.M. (1991).- Els Minerals de Catalunya. Arxius de la Secció de Ciències, t. XCIII, 442 pag. Institut d’Estudis Catalans. Barcelona.

MATA-PERELLÓ, J.M. (1995).- Recerca a través de la geografia física de set comarques de la Catalunya Central. Pub. Museu de Geologia de la UPC, 168 pàgines. Manresa.

MATA-PERELLÓ, J.M. (1996a).- Selecció d'itineraris geològics i mineralògics pel Berguedà, i per les seves comarques veïnes. Pub. Universitat Catalana d'Estiu de la Natura. 52 pàgines. Berga.

MATA-PERELLÓ, J.M. (1996b).- Recerca geològica i mineralògica per la comarca del Ripollès: des de Campdevànol a Sant Joan de les Abadesses, Surroca de Baix, Ribes de Freser i Planoles. Inèdit, 10 pàg. Manresa.

MATA-PERELLÓ, J.M. (1997).- Recorregut de recerca geològica i mineralògica per les comarques del Berguedà i del Ripollès: des de la Pobla de Lillet a Castellar de N’Hug, a Ribes de Freser i a Queralbs. Inèdit. 10 pàgines. Manresa.

MATA-PERELLÓ, J.M. (1998).- Recerca geològica i mineralògica per la comarca del Ripollès: des de Campdevànol a Ribes de Freser, Queralbs i a Planés de Rigart. Inèdit. 11 pag. Manresa.

MATA-PERELLÓ, J.M. (2007).- Recerca geològica y mineralògica per la comarca del Ripollès: des de Campdevànol a Ribes de Freser, Queralbs, Planoles i Toses. Inèdit. 12 pag. Manresa.

MATA-PERELLÓ, J.M. (2011a).- Recerca geològica i mineralògica per la comarca del Ripollès: des de Campdevànol a Ribes de Freser, Queralbs, Planoles i a Toses. Inèdit. 12 pàgines. Manresa.

MATA-PERELLÓ, J.M. i SANZ BALAGUÉ, J. (1991).- Guia de determinació dels minerals. Països Catalans i Altres. Edic. Parcir. Manresa.

RIBA ARDERIU, O. Et altri. (1976).- Geografia física dels Països Catalans. Edit Ketres. Barcelona.

MATA-PERELLÓ, J.M. (2011b).- Recorregut de recerca geològica i mineralògica per la comarca del Ripollès: des de Ribes de Freser, al Serrat, a Vilamanya i a Queralbs. Inèdit. 8 pàgines. Manresa.

SUNYER i COMA, E. (1992).- L'origen de les mineralitzacions de ferro de la Vall de Ribes, C.E.C.R., Anals 1992 - 1993, pp. 81 - 87. Barcelona. 